\title{
Environmental conditions which lead to increase in cell density of the toxic dinoflagellates Dinophysis spp. in nutrient-rich and nutrient- poor waters of the French Atlantic coast
}

\author{
Daniel Delmas, Alain Herbland, Serge Y. Maestrini \\ Centre de Recherche en Ecologie Marine et Aquaculture de L'Houmeau (CNRS-IFREMER) BP 5, F-17137 L'Houmeau, France
}

\begin{abstract}
From 22 April to 19 June 1990, 7 stations located off La Rochelle, France, from near-shore ('bassin Marennes-Oléron') to offshore waters (50 m depth contour) were visited 8 times, with the aim of determining whether the toxic dinoflagellates Dinophysis spp. increase in cell density in nutrientpoor offshore water, in nutrient-rich inshore waters, or both, and to determine their vertical distribution in relation to stratification. Temperature stratification developed offshore, but not inshore. In April, few Dinophysis spp. were present offshore and none inshore. In late May, up to $15 \times 10^{3}$ cells $\mathrm{l}^{-1}$ were recorded in the 10 to $15 \mathrm{~m}$ layer offshore, whereas inshore waters contained only a few cells $\mathrm{l}^{-1}$ In late May, a short period of wind partly modified the vertical structure, and Dinophysis spp. concentration fell, increasing again when marked stratification was again established. Through the strait, flood-tide currents moved Dinophysis spp. cells to the inshore area, and ebb-tide currents brought some of them back out. No relationship was found between Dinophysis spp. growth and availability of dissolved nutrients. We concluded that: (1) stratification of sufficient magnitude $\left(\Delta t>5^{\circ} \mathrm{C}\right)$ and duration $(>2 \mathrm{wk})$ are the factors necessary for Dinophysis spp. cell increase, and (2) inorganic nutrient input of terrestrial origin does not directly promote their growth.
\end{abstract}

\section{INTRODUCTION}

There is provocative evidence (Anderson 1989, Smayda 1990) of recent significant increases in algal biomass and production, as well as of changes in community structure and species distribution, in many inshore waters. The evidence also suggests that blooms of toxic species are becoming more frequent, particularly of the genus Dinophysis whose harmful effects are now recorded worldwide (e.g. Yasumoto et al. 1980, Kat 1983, Stamman et al. 1987, Belin et al. 1989, Karunasagar et al. 1989, Park 1991). On the contrary very little is known about the nutrients and other environmental conditions which favour increase in cell density in Dinophysis spp.

Dense populations of dinoflagellates are considered to be favoured by the relative absence of turbulence (Margalef 1975, 1978, Sournia 1982, Paerl 1988, Sommer 1988), leading to blooming in predominantly warm, stratified waters from late spring to early autumn (Smayda 1980). The few reports on Dinophysis spp. blooming are consistent with such assumptions: peak cell-density values of $D$. fortii along the coast of Ibaraki region, Japan, (Iwasaki \& Kusano 1985, Iwasaki 1986) and D. acuminata, D. acuta and D. norwegica in the Sognefjord, Norway, (Séchet et al. 1990) were recorded in June or July, when the temperature had significantly increased and the stratification of the water column was established. However, cells of D. fortii, undetectable in winter, have been observed in the Mutsu Bay as soon as the temperature of surface water exceeded $8^{\circ} \mathrm{C}$ (Ozaka 1985).

So far, there have been no data to show clearly whether relatively dense populations of any Dinophysis spp. result from active growth, from mass transport and accumulation, or from both. Moreover, several results are conflicting. In immersed tanks, Brockmann et al. (1977) observed growth of D. acumi- 
nata leading to maximum cell densities when macronutrients were still available, and Clément (1985) reported peak densities of the same species in nutrient-rich water of the 'Mor-Braz' (French Atlantic coast). While these findings suggest that density increases can take place by nutrient uptake and growth, similar peak densities of $D$. acuminata were observed in nitratefree and phosphorus-poor water of nearby Vilaine Bay (Lassus et al. 1985), and other Dinophysis spp. in both offshore and inshore waters along the French Atlantic coast (Lassus et al. 1989). Igarashi (1985) and Iwasaki (1986) have also demonstrated that $D$. fortii grows first in offshore waters and is transported to coastal bays by currents, and Haamer et al. (1990), according to results of transplantation experiments of mussels along the Swedish coast, hypothesized a similar mechanism for most of the toxic plankton.

In the light of these findings, a research program was carried out in the vicinity of La Rochelle on the French Atlantic coast, to answer the following questions: (1) What environmental conditions lead to increases of cell density? (2) Does growth occur first in offshore waters, inshore populations resulting from movement from offshore? (3) What nutrient source, if any, is the most closely related to Dinophysis growth? (4) Subsequently, does coastal eutrophication increase Dinophysis biomass? The first data, obtained in May 1989, indicated that Dinophysis spp. numbers increase mostly in stratified and nutrient-poor offshore waters (Delmas et al. 1990). However the increase recorded was too small to allow this to be stated conclusively. We therefore repeated this research in April, May and June 1990, after elimination of redundant sampling stations

\section{MATERIALS AND METHODS}

The sampling area comprised 3 zones (Fig. 1): (1) an island-enclosed basin ('bassin de Marennes-Oléron') whose waters are enriched in nutrients by 2 rivers (the Charente and the Seudre) and which supports important oyster and mussel installations, (2) a strait ('pertuis d'Antioche') separating this enclosed bay from (3) the open sea. On part of the transect from the mainland coast to offshore water (here investigated out to a depth of $50 \mathrm{~m}$ ), occurs a trench (maximum depth $50 \mathrm{~m}$ ). Separating this trench from the open sea is water of at least $25 \mathrm{~m}$ depth.

Two research vessels were used: the 'Côte d'Aquitaine' (Centre National de la Recherche Scientifique, CNRS) and the 'Gwen-Drez' (Insitut Français de Recherche pour l'Exploitation de la Mer, IFREMER).

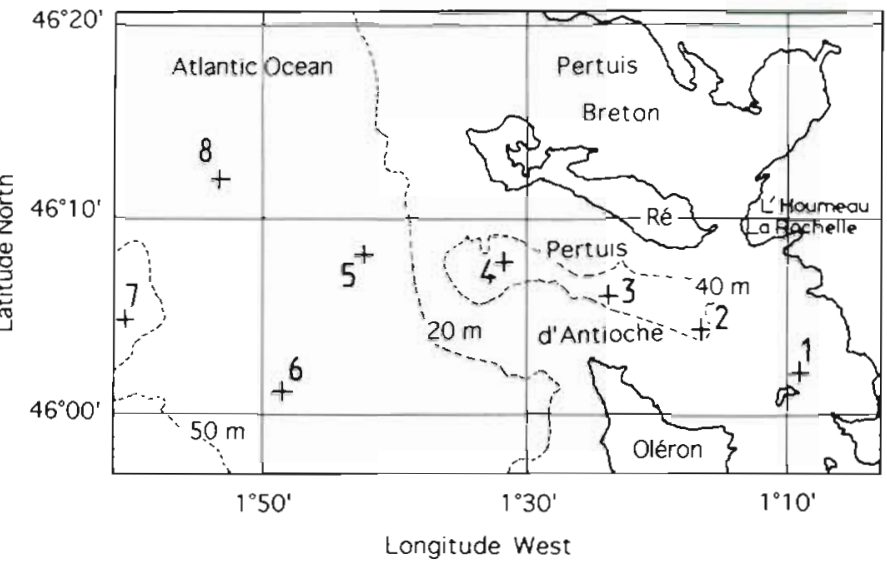

Fig. 1. Study area and positions of sampling stations off La Rochelle, France

Stns 1 to 5 and Stn 7 were situated along the transect. Two others (Stns 6 and 8) were also worked (Fig. 1). All were visited 8 times, at approximately weekly intervals from 21 April to 19 June. In addition, a $72 \mathrm{~h}$ standing station was worked in the 'bassin' at both the western limit of the Charente plume (Ravail et al. 1987) and the northern limit of shellfish culture installations (Stn 2).

At each station, a vertical profile of salinity and temperature (CTD ECO 36 probe, Meerestechnike Elektronik) was recorded. Samples for further analyses were mostly taken in the thermocline layer and the mixed upper layer.

Samples for nutrient analysis were kept at $-20^{\circ} \mathrm{C}$. Analyses were done with a Skalar automatic analyser; analytical protocols were those of Strickland \& Parsons (1972) for $\mathrm{NO}_{3}, \mathrm{NO}_{2}, \mathrm{PO}_{4}$ and $\mathrm{SiO}_{3}$, and Koroleff (1976, 1983) for $\mathrm{NH}_{4}$ and urea, respectively. Fluorescence of methanol-extracted chlorophyll $a$ and phaeopigments (Yentsch \& Menzel 1963, Holm-Hansen \& Riemann 1978) was measured on board with a Turner 112 fluorometer. Samples (2 1) for phytoplankton cell counting were preserved with a lugol-formol mixture, then concentrated to $250 \mathrm{ml}$ and treated according to Utermöhl (1931), with sedimentation columns of $20 \mathrm{mI}$.

\section{RESULTS}

Variations observed from late April to mid June, and from inshore to offshore waters

Over this period, the surface temperature increased markedly; from $11.6-11.9^{\circ} \mathrm{C}$ (22 April) to $16.6-18.8^{\circ} \mathrm{C}$ (31 May). However, short periods of wind and turbulence led to some slight, temporary decreases; on 19 June, for instance, the range of temperatures had decreased to $14.6-17.4^{\circ} \mathrm{C}$. In inshore waters (Stn 1; 


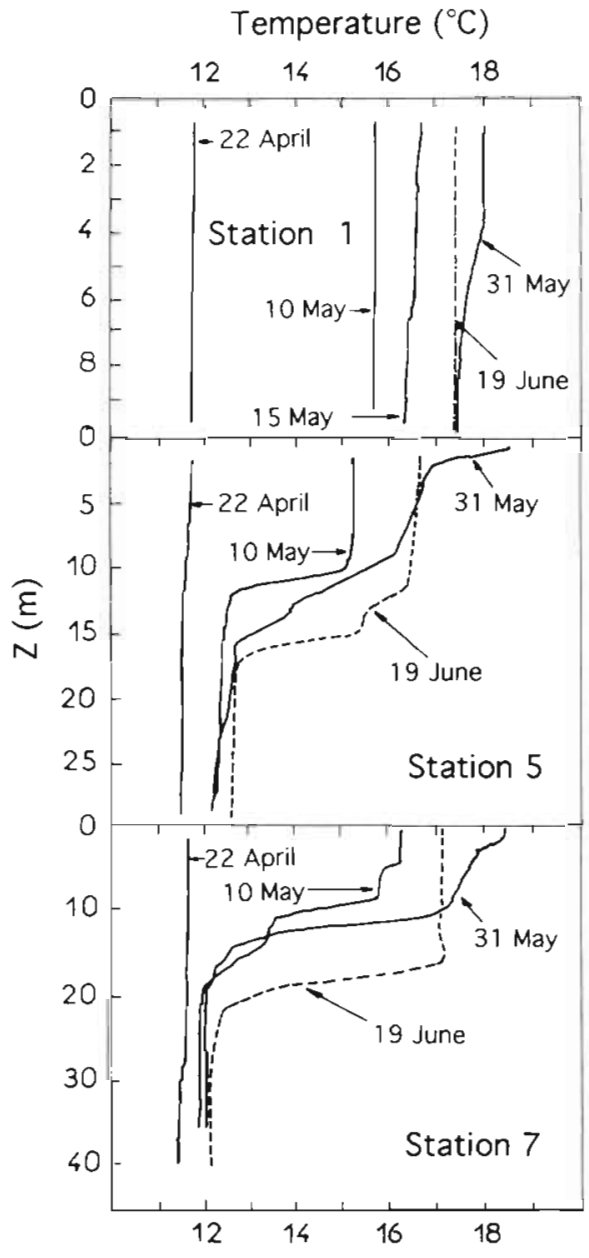

Fig. 2. Typical temperature vertical profiles inshore (Str. 1), at entrance to strait (Stn 5) and offshore (Stn 7) from 22 April to 19 June

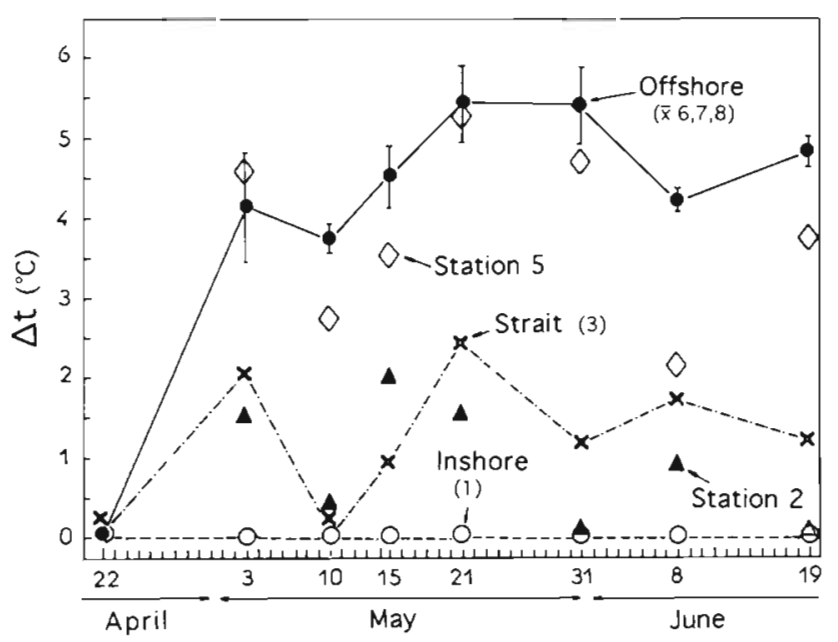

Fig. 3. Temperature differences within the thermocline $(\Delta t)$ inshore (Stn 1), in strait (Stn 3), at entrance to strait (Stn 5) and offshore (Stns 6, 7 and 8) from 22 April to 19 June
Fig. 1), the temperature increase always involved the whole water column, as tidal mixing prevented any stratification (Figs. $2 \& 3$ ). In the offshore area (i.e. Stns 6,7 and 8 ; Fig. 1), however, the water column stratified in late April, and between 10 May and 19 June a thermocline was established with $\Delta t=3.5$ to $5.5^{\circ} \mathrm{C}$ (Fig. 3; $\Delta t=$ temperature at the base of the upper mixed layer minus the temperature of the bottom layer) Some CTD records showed a sharp thermocline (Fig. 2). Temperature vertical profiles in areas between the 2 extremes showed intermediate and variable values. However, the thermocline at stations both between the strait (pertuis d'Antioche) and mainland coast and in the strait always remained weak $\left(\Delta t \leq 2.3^{\circ} \mathrm{C} ;\right.$ Fig. 3). Outside the strait, 2 stations (4 and 5) with only ca $25 \mathrm{~m}$ deep water also showed variable values of $\Delta t$. Only Stns 6,7 and 8 , all in deep water (25 to $50 \mathrm{~m}$ ), showed consistently similar values of $\Delta t$.

Offshore (Stns 5 to 7 ), the reservoir of nitrogenous nutrients $(\Sigma N)$ did not decrease significantly; within the $20 \mathrm{~m}$ upper layer, it always remained around $2 \mu \mathrm{mol} \mathrm{N}]^{-1}$ [Fig. 4; the $20 \mathrm{~m}$ upper layer was used as a basis for integrated 'available' nutrient levels because previous results of Delmas et al. (1990) indicated

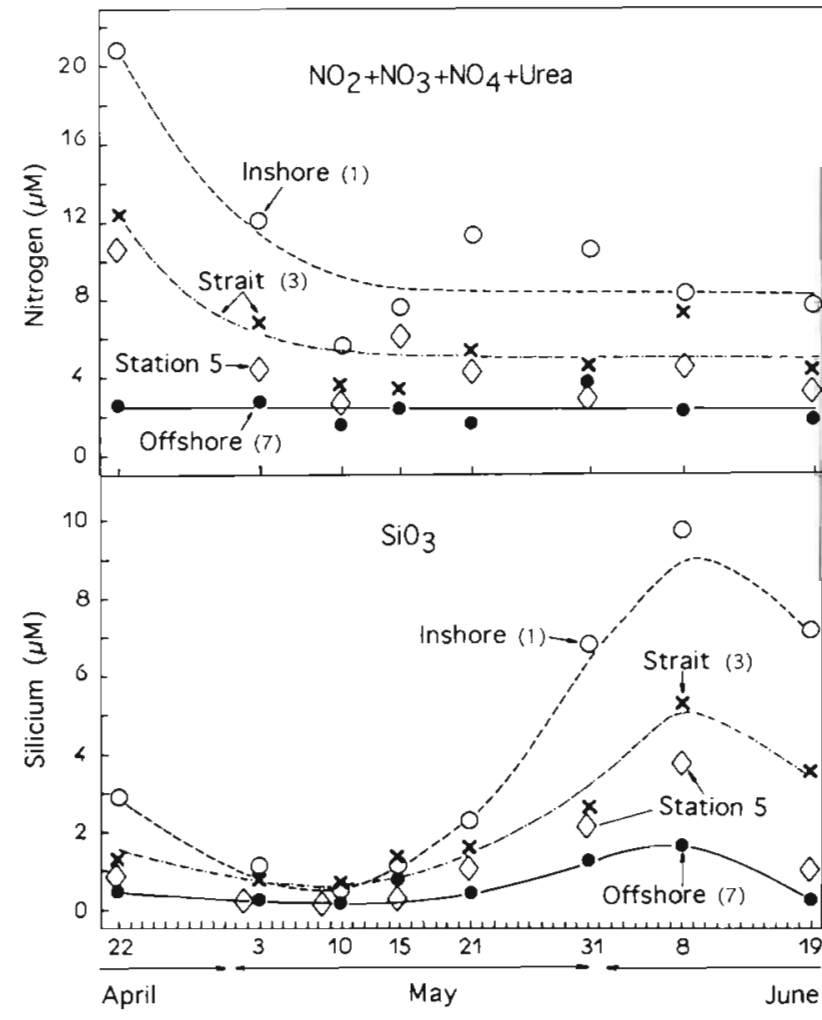

Fig. 4. Total dissolved nitrogen $\left(\sum \mathrm{N}=\mathrm{NO}_{2}+\mathrm{NO}_{2}+\mathrm{NH}_{4}+\right.$ Urea) and $\mathrm{SiO}_{3}$ concentrations in the upper layer $(0$ to $20 \mathrm{~m}$ integrated values) measured inshore (Stn 1), in strait (Stn 3) at entrance to strait (Stn 5) and offshore (Stn 7) from 22 April to 19 June 
that most Dinophysis spp. cells occurred in that layer]. Nevertheless, the respective importance of the different chemical forms changed greatly. While in late April $\mathrm{NO}_{2}+\mathrm{NO}_{3}$ represented $76 \%$ of total available nitrogen (i.e. $\mathrm{NO}_{2}+\mathrm{NO}_{3}+\mathrm{NH}_{4}+$ Urea) and there was no detectable urea, by late June, $\mathrm{NO}_{2}+\mathrm{NO}_{3}$ represented $38 \%, \mathrm{NH}_{4} 6 \%$ and urea $56 \%$ of the total, $2 \mu \mathrm{mol} \mathrm{N} \mathrm{l} l^{-1}$. At all other stations, the early spring nutrient concentrations started higher and a significant decrease occurred during the spring, but also with no exhaustion of the reservoir. Inshore waters always remained far richer than offshore waters: the lowest average values of $\Sigma N$ concentration was $8 \mu \mathrm{M}$ near the mainland coast, against $2 \mu \mathrm{M}$ in the open sea. Moreover, $\mathrm{NO}_{2}+\mathrm{NO}_{3}$ represented $95 \%$ of $\Sigma \mathrm{N}$ in late April, and still $75 \%$ in late June. Silicate evolved quite differently: after an initial decrease, concentrations of $\mathrm{SiO}_{3}$ increased significantly for about 1 mo (10 May to 8 June) and then decreased again (Fig. 4). Nearshore waters were also far richer in silicate than offshore waters. Phosphorus concentrations were rather scattered, except in nearshore water where they always remained within the range 0.12 to $0.24 \mu \mathrm{M}$, and in the open sea (Stns 5 to 8) phosphate was at times undetectable (data not shown).

The chlorophyll a content of the euphotic layer showed a pattern in offshore waters quite different from that inshore. Offshore (e.g. Stn 7; Fig. 5), the maximum content was recorded in late April; the chlorophyll a concentration then decreased and remained low. In water close to the mainland and in the strait, mean 0 to $20 \mathrm{~m}$ concentrations of chlorophyll a were high in early May ( 3 to 10 May), then a decrease followed, with a minimum in late May (inshore) and early June (strait) after which algal levels increased

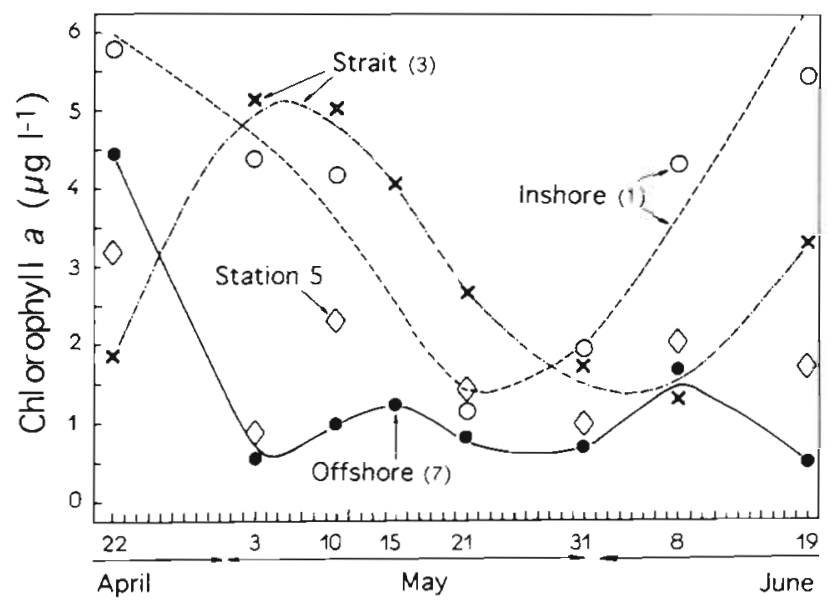

Fig. 5. Chlorophyll a concentration in the upper layer ( 0 to $20 \mathrm{~m}$ integrated value), measured inshore (Stn 1), in strait (Stn 3), at entrance to strait (Stn 5) and offshore (Stn 7) from 22 April to 19 June again. In the strait, this second growth period led to modest chlorophyll a concentrations when sampling ended. In inshore water, growth was faster (Fig. 5).

Of the few cells of Dinophysis spp. counted in late April, almost all occurred in offshore waters (Fig. 6). A

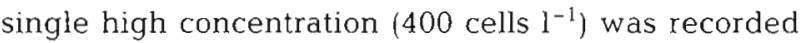
outside the strait (Stn 5). On 3 May, still outside the strait, a narrow sub-surface layer hosted a population whose concentration varied between 240 and 390 cells $1^{-1}$. By mid May, this patch had extended over the whole study area, and a layer of higher concentration

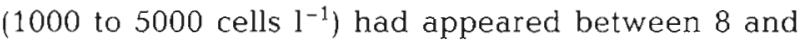
$15 \mathrm{~m}$ depth in offshore waters (Stns 5 to 8 ).

At the end of May, another significant increase in Dinophysis spp. density had occurred over the whole area, but with large differences depending on both distance offshore and depth. In the entrance to the strait (Stn 5), from surface to ca $10 \mathrm{~m}$ in depth, the concentration of Dinophysis spp. ranged from 5000 to 10000 cells $1^{-1}$, and peaked at nearly 15000 cells $1^{-1}$ between 10 and $15 \mathrm{~m}$ depth. This $5 \mathrm{~m}$ layer with the highest cell density was also present towards the open sea, but at different depths: 24 to $29 \mathrm{~m}$ at the most offshore station ( $\operatorname{Stn} 7,23 \mathrm{n}$ mile from $\operatorname{Stn} 5$ ), and 0 to $10 \mathrm{~m}$ in the southwest (Stn 6, $14 \mathrm{n}$ mile from Stn 5). In the northwest area (Stn 8), the concentration remained

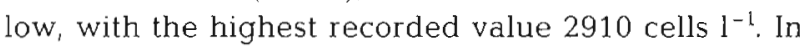
the strait (Stns 2, 3, 4), Dinophysis spp. concentrations remained lower by 1 order of magnitude, with the highest recorded value 1150 cells $^{-1}$ The shape of the vertical distribution was similar to that offshore, however, with few or no cells in the upper $3 \mathrm{~m}$, highest values (200 to 1000 cells $^{-1}$ ) between 3 and $12 \mathrm{~m}$, and few or no cells deeper than $12 \mathrm{~m}$. In the waters closest to the shore (Stn 1), few or no Dinophysis spp. occurred at any depth.

By June 8 , after a period of high wind in early June, $\Delta t$ values offshore had declined, Dinophysis spp. concentration was far less stratified, and values

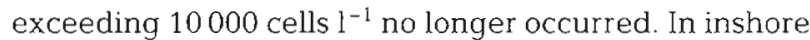
waters (Stns 1 and 2), concentrations had declined below 100 cells $\mathrm{l}^{-1}$, and no cells at all were seen in either surface or bottom waters from near shore (Stn 1). In the strait entrance and in open-ocean waters, densities ranging from 1000 to 5000 cells $1^{-1}$ still occurred, and in this area cells were still more numerous in the 18 to $22 \mathrm{~m}$ layer, while densities as high as 2330 cells $\mathrm{I}^{-1}$ also occurred in the upper $10 \mathrm{~m}$ at the outer Stn 7 .

On 19 June when sampling ended, the stratified vertical distribution formed in late May was still present. Outside the strait (Stn 5) there were 6240 cells $l^{-1}$ in the 0 to $3 \mathrm{~m}$ upper layer; their concentration decreased with depth, with only 680 cells $l^{-1}$ in near-bottom water. In the offshore waters (Stn 7), few cells were present in the upper layer, while from 5 to $20 \mathrm{~m}$ depth, 


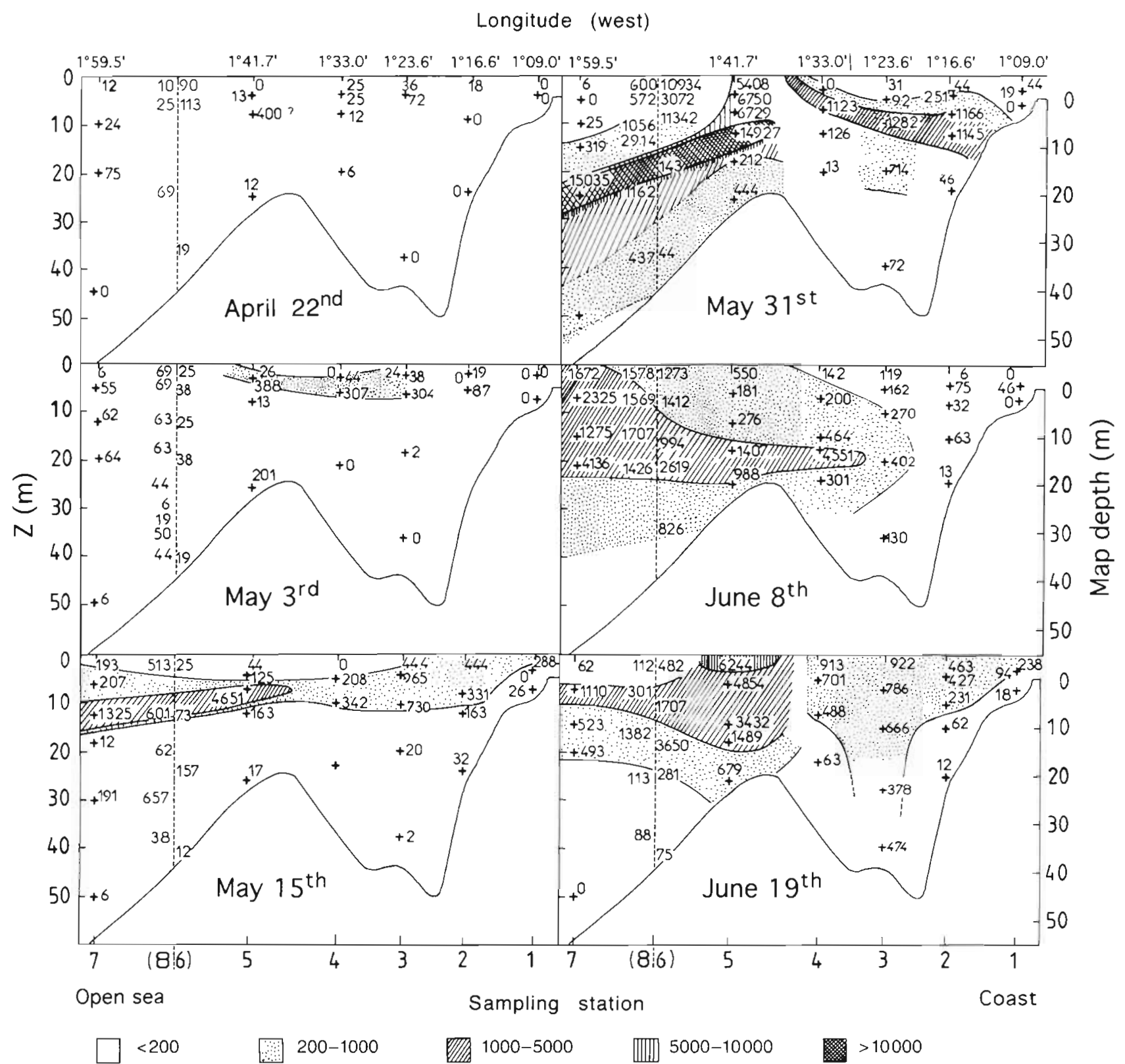

Fig. 6. Dinophysis spp. Cell density along the transect from the coast (Stn 1) to the open sea (Stn 7) from 22 April to 19 June. Data of offshore Stns 6 and 8 which were not on the transect are indicated but not directly taken into account in drawing isopleths

the concentration ranged between 500 and 1100 cells $\mathrm{l}^{-1}$, and again there were hardly any cells below 22 to $25 \mathrm{~m}$. In the strait entrance, the strait and inshore waters, Dinophysis spp. were present at 200 to 1000 cells $\mathrm{I}^{-1}$ from the surface to $15 \mathrm{~m}$ depth. Lowest values were recorded in nearshore water ( $\operatorname{Stn} 1)$.

\section{Short-term variations in inshore water (Stn 2)}

At the limit of salinity influence by the Charente River (Stn 2), the flood-tide drove offshore-like waters towards the coast, whereas the ebb-tide drove them back out to sea. Within the 0 to $10 \mathrm{~m}$ upper layer, salinity thus oscillated smoothly between highest and lowest values with the tidal cycle (Fig. 7). The Dinophysis spp. concentration in these waters also fluctuated in phase with salinity: at low tide, few were present in low-salinity waters (i.e. ca 10 to 60 cells $1^{-1}$ ); on the contrary, at high tide, higher values

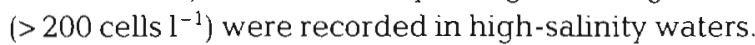

Salinity and Dinophysis spp. Concentration also varied with tidal amplitude; on a mean-amplitude tide (coefficient 85), they both followed the tide wave 


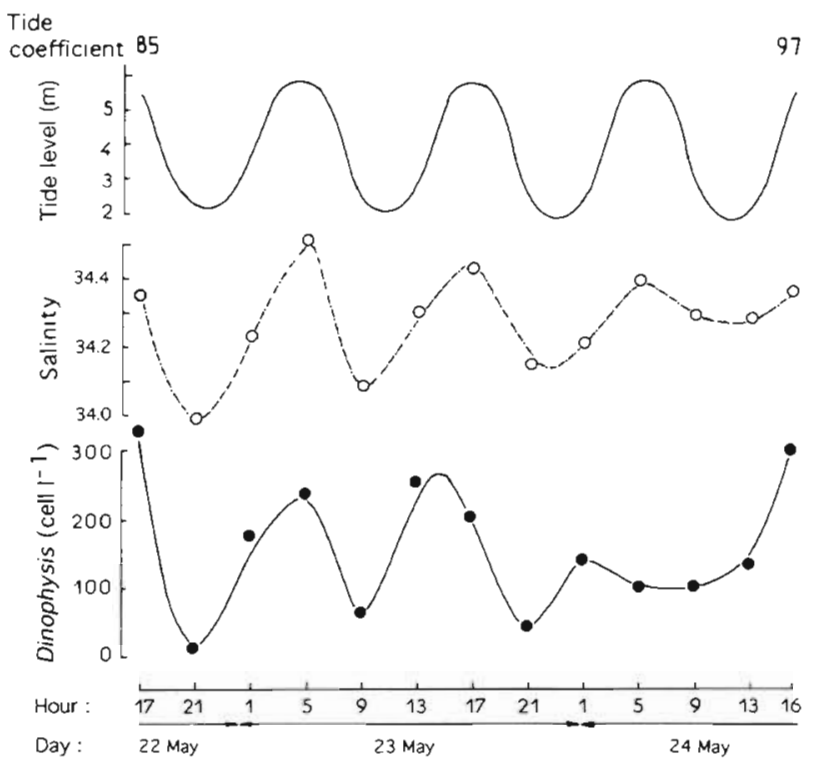

Fig. 7. Mean salinity and Dinophysis spp. cell density $(0$ to $10 \mathrm{~m}$ integrated values) in relation to the tide in strait (Stn 2) from 22 to 24 May

closely; at spring tides (coefficient 97), variations were smooth but values indicated that offshore water was now driven back less by the ebb current.

\section{DISCUSSION}

The concentration of Dinophysis spp. increased most rapidly from mid to late May. At that time, the spring bloom of other algal components (Fig. 5) had already greatly reduced the nutrient (nitrogen) reservoir in all parts of the study area, yet it was nowhere exhausted (Fig. 4). In addition, the maximum cell concentrations were recorded in the nutrient-poorest offshore waters (Stns 5, 6 and 7, 31 May; Fig. 6), whereas inside the basin (Stns 3 and 2) cells were less abundant by at least 1 order of magnitude. Moreover, Dinophysis spp. rarely increased in abundance in the estuarine plume water relative to winter concentrations, despite the presence of terrestrial nutrients (Stn 1), and several samples contained no cells at all.

All included, there was no relationship between concentration of Dinophysis spp. and the availability of dissolved nutrients. River-borne nutrients from agricultural and domestic origins thus did not promote growth of the local Dinophysis spp. population in the inshore area. Nevertheless, since in the Seine plume (France) peak cell densities of Dinophysis cf. acuminata have been observed to parallel increased nitrate concentration (Lassus et al. 1991), indirect stimulating effects of inorganic nutrient richness should be considered as a possibility.

That no relationship was found between the biomass of Dinophysis spp. and nutrient concentration conflicts with previous assumptions about the nutritional requirements of Dinophysis spp. (Menesguen et al. 1990). Some of these assumptions have recently been shown to be incorrect. For instance $D$. hastata and $D$. schuettii (Hallegraeff \& Lucas 1988), as well as D. rotundata (Hansen 1991) are now known to be phagotrophic. Nevertheless, most Dinophysis spp. contain chloroplasts (Hallegraeff \& Lucas 1988, Schnepf \& Elbrächter 1988) which a photosynthetic capacity (Durand Clément et al. 1988, Hallegraeff \& Lucas 1988), and ability to take up inorganic nutrients. No experimental evidence, however, yet exists to support such an assumption, mainly because of failure to culture these organisms.

Some recent data suggest mixotrophic nutrition for some of those species with chloroplasts. Jacobson (in press) found that $13 \%$ of Dinophysis acuminata cells showed vacuoles containing ingested particules, together with well-developed chloroplasts. Granéli et al. (in press) have furthermore demonstrated incorporation of inorganic ${ }^{14} \mathrm{C}$ by $D$. acuminata and $D$. norvegica in the light, but suggest that dissolved organic substances released by autotrophic plankton or phagotrophy may provide additional sustenance at night. Nevertheless, the nutritional requirements of $D$. acuminata and the nutritional factors which sustained its growth in the water we studied still remain unknown, while those of $D$. acuta, D. caudata, D. sacculus and $D$. tripos have been never studied at all.

Prior to the large increase in Dinophysis spp. concentration, marked stratification of the water column had established offshore. Above the entrance to the strait (Stn 5), where nearly 5000 cells $1^{-1}$ were counted on 15 May (Fig. 6), the temperature difference across the thermocline $(\Delta t)$ had reached $3.5^{\circ} \mathrm{C}$ since late April. Furthermore, by late May $\Delta t$ had increased to $4.4^{\circ} \mathrm{C}$ and the Dinophysis spp. Concentration to 15000 cells $l^{-1}$. The link with the stratified conditions seems well established, since at Stn 5 Dinophysis spp. concentration fell to the 10000 cells $1^{-1}$ range when the water column was partly destratified (i.e. $\Delta t=2.1^{\circ} \mathrm{C}$ ) by a short period of wind ( 8 June), but increased again when stratification re-established (19 June). There was a quite good correlation $\left(\mathrm{r}^{2}=0.63 ; \mathrm{n}=21\right)$ between the depths at which the peak Dinophysis spp. concentrations and the respective depths of the middle of the thermocline were recorded (Fig. 8).

On the other hand, in inshore water (Stn 2), where the water column was never stratified (Fig. 3), Dinophysis spp. remained scarce. It can therefore be assumed that a well-established stratification of the water column of sufficient duration is the key environ- 


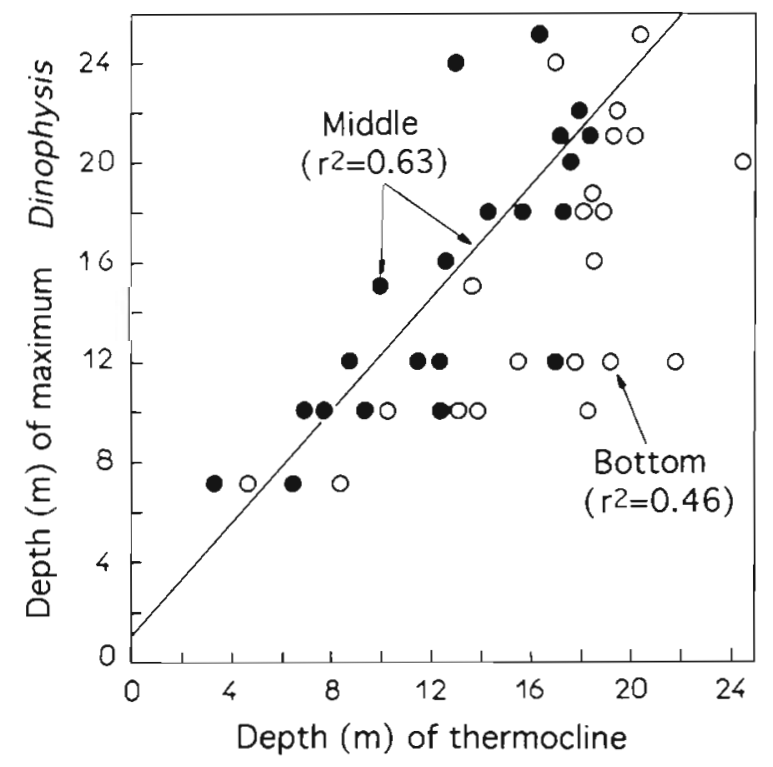

Fig. 8. Depth of the greatest Dinophysis spp. concentration vs depth of the bottom $(0)$ and the middle $(\bullet)$ of the thermocline at offshore stations (Stns 4, 5,6 and 7) from 15 May to 19 June

mental condition promoting the increase of Dinophysis spp. cell density in the study area. Similar findings by Jones \& Gowen (1990) and Raine et al. (1990) involving other dinoflagellates support this assumption. Moreover, Raine et al. (1990), by comparing a thermallystratified bay and a salinity-stratified harbour area, abserved that only the thermally-originated stratification favoured the accumulation and dominance of dinoflagellates.

Turbulence can keep populations of non-motile cells in the surface mixed photic layer, allowing them to maintain their biomass when growth rate exceeds losses due to grazing, sinking and diffusion (Platt et al. 1977). Without turbulence, non-motile cells sink and the population disappears, but motile cells can remain in the euphotic layer and dominate (Margalef 1978, Bowman et al. 1981, Jones \& Gowen 1990). Turbulence also specifically affects several physiological processes, such as uptake capabilities (Pasciak \& Gavis 1974, Gavis 1976) and thus partly control the nutrient-based competition in natural assemblages, as experimentally demonstrated by Estrada et al. (1987). All included, dinoflagellates are the most sensitive to turbulence (Thomas \& Gibson 1990). By early May, when Dinophysis spp. began to increase significantly in offshore stratified water, reduction of turbulence and subsequent sinking may therefore have eliminated most of the nonmotile competitors; the highest chlorophyll a concentration was in fact recorded near the bottom, strongly suggesting sedimentation of species whose biomass had been maximum in mid April.
Disappearance by sinking of most non-motile competitors, however, is unlikely to be the sole explanation for the cell density distribution we observed. Although the vertical distribution of samples was not close enough to show small-scale peaks of density, Dinophysis spp. appear to have accumulated in a layer a few metres thick situated between the top and the bottom of the thermocline. That their maximum density was almost always recorded in the middle or the underside of thermocline (Fig. 8) supports this hypothesis, as do findings of Bjornsen \& Nielsen (1991) who used a decimeter-scale sampler and reported that in the Kattegat (Denmark) some dinoflagellates were in summer confined to a $1 \mathrm{~m}$ thick layer which contained more chlorophyll than the rest of the water column.

The mechanism responsible for the observed vertical distribution of Dinophysis spp. cells could be one or a combination of the following: (1) sinking of senescent cells and accumulation because the pycnocline acts as a barrier (e.g. the 1988 Chrysochromulina polylepis bloom; Maestrini \& Graneli 1991), (2) growth might be better due to decrease of stress originating from turbulence (Thomas \& Gibson 1990) or to (3) detrital material produced in the surface-mixed layer which can accumulate at the pycnocline (Sieburth 1991), (4) active vertical migration may occur to meet nutrientrich water (Blasco 1978, Olsson \& Graneli 1991 and references therein) or (5) highest available photon flux density (Rasmussen \& Richardson 1989). Up to now, however, there is no evidence to say which of these mechanisms may have acted on the Dinophysis spp. we observed.

The Dinophysis spp. appear earlier and at higher concentrations in the open sea before they do near shore and flood-tide currents carry them from offshore to inshore waters, whereas ebb-tide currents carry some cells back out (Fig. 7). This mechanism could have an important practical consequence: mussels grown on vertical ropes in those installations closest to the open sea are likely to accumulate diarrhetic shellfish poison(s) before those grown near the coast. On the other hand, it can be predicted that during stratification of the water column, mussels grown on ropes will concentrate more diarrhetic toxin at the thermocline level than those placed near the surface. The new open-sea mussel farms, whose number is growing in France (Maestrini et al. 1990), could therefore act as a large-scale experiment if Dinophysis spp. continue to bloom in the future.

Acknowledgements. This work was supported by the 'Programme national Efflorescences algales marines'. We warmly thank captains Michel Jaffrezic ('Côte d'Aquitaine', CNRS) and Roland Mornet ('Gwen Drez', IFREMER) and their crews for help at sea, Mrs Françoise Mornet and Miss Lucette 
Joassard (L'Houmeau) for work at sea, nutrient analysis and phytoplankton counting, Mrs Evelyne Travers (L'Houmeau) for preparation of the manuscript and Dr Ian Jenkinson (ACRO, La Roche Canillac) for improving the English version.

\section{LITERATURE CITED}

Anderson, D. M. (1989). Toxic algal blooms and red tides: a global perspective. In: Okaichi, T., Anderson, D. M., Nemoto, T. (eds.) Red tides: biology, environmental science, and toxicology. Elsevier, New York, p. 11-16

Belin, C., Berthomé, J. P., Lassus, P. (1989). Dinoflagellés toxiques et phénomènes d'eaux colorées sur les côtes françaises: évolution et tendances entre 1975 et 1988. Equinoxe 25: 30-38

Bjornsen, P. K., Nielsen, T. G. (1991). Decimeter scale heterogeneity in the plankton during a pycnocline bloom of Gyrodinium aureolum. Mar. Ecol. Prog. Ser. 73: 263-267

Blasco, D. (1978). Observations on the diel migration of marine dinoflagellates off the Baja California coast. Mar. Biol. 46:41-47

Bowman, M. J., Esaias, W. E., Schnitzer, M. B. (1981). Tidal stirring and the distribution of phytoplankton in Long Island and Block Island Sounds. J. mar. Res. 39: 587-603

Brockmann, U. H., Eberlein, K., Hosumbek, P., Trageser, H., Maier-Reimer, E., Schöne, H. K., Junge, H. D. (1977). The development of a natural plankton population in an outdoor tank with nutrient-poor sea water. I. Phytoplankton succession. Mar. Biol. 43: 1-17

Clément, J. C. (1985). Qualité des eaux du Mor-Bras: résultats complémentaires issus des campagnes 1983. Cahiers du Mor-Bras, 7. Ass. Halieut. Mor-Bras, Vannes, p. 1-106

Delmas, D., Herbland, A., Maestrini, S. Y., Mornet, F. Morand, P., Spano, A. M., Burgeot, T., Margat, S., Charpentier, G., Fillon, A., Leguay, D., Thomas, G., Bacher, C., Héral, M., Prou, J. (1990). Conditions d'apparition de densités accrues de dinoflagellés Dinophysis dans le pertuis d'Antioche et les eaux adjacentes. Campagnes Dinopertuis 89. Campagnes Océanographiques Françaises 12 IFREMER, Plouzane, p. 1-82

Durand Clément, M., Clément, J. C., Moreau, A., Jeanne, N., Puiseux-Dao, S. (1988). New ecological and ultrastructural data on the dinoflagellate Dinophysis sp. from the French coast. Mar. Biol. 97: 37-44

Estrada, M., Alcaraz, M., Marrasé, C. (1987). Effects of turbulence on the composition of phytoplankton assemblages in marine microcosms. Mar. Ecol. Prog. Ser. 38: 267-281

Gavis, J. (1976). Munk and Riley revisited: nutrient diffusion transport and rates of phytoplankton growth. J. mar. Res. 34: $161-179$

Granéli, E., Anderson, D. M., Maestrini, S. Y., Paasche, E. (in press). Light and dark carbon fixation by the marine dinoflagellate genera Dinophysis and Ceratium. In: Li, W., Maestrini, S. Y. (eds.) Measurement of primary production from the molecular to the global scale. ICES Mar. Sci. Symp., La Rochelle, 21-24 April 1992

Haamer, J., Andersson, P. O., Lindahl, O., Lange, S. (1990). Geographic and seasonal variation of okadaic acid content in farmed mussels, Mytilus edulis Linnaeus, 1758, along the Swedish west coast. J. Shellfish Res. 9 (1): $103-108$

Hallegraeff, G. M., Lucas, I. A. N. (1988). The marine dinoflagellate genus Dinophysis (Dinophyceae): photosynthetic, neritic and non-photosynthetic, oceanic species. Phycologia 27(1): 25-42
Hansen, P. J. (1991). Dinophysis - a planktonic dinoflagellate genus which can act both as a prey and a predator of a ciliate. Mar. Ecol. Prog. Ser. 69: 201-204

Holm-Hansen, O., Riemann, B. (1978). Chlorophyll a determination: improvements in methodology. Oikos 30 $438-447$

Igarashi, T. (1985). Sanriku coasts. In: Fukuyo, Y. (ed.) Biology and ecology of shellfish poisoning plankton. Bull. Jap. Soc. scient. Fish. 56: p. 71-81 (in Japanese)

Iwasaki, J. (1986). The mechanism of mass occurrence of Dinophysis fortii along the coast of Ibaraki prefecture. Bull. Tohoku reg. Fish. Res. Lab. 48: 125-136

Iwasaki, J., Kusano, K. (1985). Kashimanada In: Fukuyo, Y. (ed.) Biology and ecology of shellfish poisoning plankton. Bull. Jap. Assoc. scient. Fish. 56: 82-97 (in Japanese)

Jacobson, D. M. (in press). Comparative ultrastructure of the food vacuoles of Dinophysis acuminata, Dinophysis rotundata and Oxyphysis oxytoxoides. In: Smayda, T. J., Shimizu, Y (eds.) Proc. 5th international conference on toxic marine phytoplankton, Oct. 28-Nov. 1, 1991, Newport, RI. Elsevier, Amsterdam

Jones, K. J., Gowen, R. J. (1990). Influence of stratification and irradiance regime on summer phytoplankton composition in coastal and shelf seas of the British isles. Estuar. coast. Shelf Sci. 30: $557-567$

Karunasagar, I., Segar, K., Karunasagar, I. (1989). Incidence of PSP and DSP in shellfish along the coast of Karnataka state (India). In: Okaichi, T., Anderson, D. M., Nemoto, T. (eds.) Red tides: biology, environmental science, and toxicology. Elsevier, New York, p. 61-64

Kat, M. (1983). Diarrhetic mussel poisoning in the Netherlands related to the Dinoflagellate Dinophysis acuminata. Antonie van Leeuwenhoek 49(4/5): 417-427

Koroleff, F. (1976). Determination of ammonia. In: Grasshoff, K., Ehrhardt, M., Kremling, K. (eds.) Methods of sea water analysis. Verlag Chemie, Weinheim, p. 126-133

Koroleff, F. (1983). Determination of urea. In: Grasshoff, K, Ehrhardt, M., Kremling, K. (eds.) Methods of sea water analysis. Verlag Chemie, Weinheim, p. 158-162

Lassus, P., Martin, A. G., Maggi, P., Berthomé, J. P., Langlade, A., Bachère, E. (1985). Extension du dinoflagellé Dinophysis acuminata en Bretagne sud et conséquences pour les cultures marines. Rev. Trav. Inst. Pêch. marit. 47 ( 3 et 4$)$ : $122-133$

Lassus, P., Truquet, P., Le Dean, L., Bardouil, M. (1989). Hydrologie et distribution de Dinophysis en juin 1988, dans la frange côtière nord-Gascogne. Rapport DERO/8908-MR. IFREMER, Paris, p. 1-69

Lassus, P., Herbland, A., Lebaut, C. (1991). Dinophysis blooms and toxic effects along the French coast. World Aquaculture 22(4): $49-54$

Maestrini, S. Y., De Lamare, J. M., Harache, Y., Hussenot, J., Querellou, J., Loste, C., Massé, J., Sourisseau, B. (1990). Valorisation et diversification des sites aquacoles en eaux marines et saumâtres du territoire métropolitain français. Equinoxe 33: 20-31

Maestrini, S. Y., Granéli, E. (1991). Environmental conditions and ecophysiological mechanisms which led to the 1988 Chrysochromulina polylepis bloom: an hypothesis. Oceanol. Acta 14(4): 1-17

Margalef, R. (1975). Assessment of the effects on plankton. In: Pearson, E. A., Frangipane, O. (eds.) Marine pollution and marine waste disposal. Pergamon Press, Oxford, $p$. 301-306

Margalef, R. (1978). Life-forms of phytoplankton as survival alternatives in an unstable environment. Oceanol. Acta 1(4): 493-509 
Menesguen, A., Lassus, P., De Cremoux, F., Boutibonnes, L. (1990). Modelling Dinophysis blooms: a first approach. In Granéli, E., Sundström, B, Edler, L., Anderson, D. M. (eds.) Toxic marine phytoplankton. Proc. 4th lnt. Conf. Toxic Mar. Phytoplank., 26-30 June 1989, Lund, Sweden. Elsevier, New York, p. 195-200

Olsson, P., Granéli, E. (1991). Observations on diurnal vertical migration and phased cell division for three coexisting marine dinoflagellates. J. Plankton Res. 13(6): 1313-1324

Ozaka, Y (1985). Mutsu bay. In: Fukuyo, Y. (ed.) Biology and ecology of shellfish poisoning plankton. Bull. Jap. Soc. scient. Fish. 56: 59-70 (in Japanese)

Paerl, H. W. (1988). Nuisance phytoplankton blooms in coastal, estuarine, and inland waters. Limnol. Oceanogr. 33 (4, part 2): $823-847$

Park, J. S. (1991). Red tide occurrence and countermeasure in Korea. In: Park, J. S., Kim, H. G. (eds.) Recent approaches on red tides. Proc. 1990 Korean-French seminar on red tides Nov. 9-10 1990. Nat. Fish. Res. and Develop. Agency, Republic of Korea. National Fisheries Research and Development Agency, Kijang-up, Yangsan-gun, Kyongsangnamdo, 626-900, Republic of Korea, August 1991, p. 1-24

Pasciak, W. J., Gavis, J. (1974). Transport limitation of nutrient uptake in phytoplankton. Limnol. Oceanogr. 19: 881-888

Platt, T., Denman, K. L., Jassby, A. D. (1977). Modeling the productivity of phytoplankton. In: Goldberg, E. D et al. (eds.) The sea: ideas and observations on progress in the study of the seas, Vol. 6. Wiley, New York, p. 807-856

Raine, R., McMahon, T., O'Mahony, J., Moloney, M., Roden, C. (1990). Water circulation and phytoplankton populations in two estuaries on the west coast of Ireland. In: Chambers, P. L., Chambers, C. M. (eds.) Estuarine ecotoxicology. JAPAGA, p. 19-28

Rasmussen, J., Richardson, K. (1989). Response of Gonyaulax tamarensis to the presence of a pycnocline in an artificial water colomn. J. Plankton Res. 11(4): 747-762

Ravail, B., Héral, M., Maestrini, S. (1987). Incidence du débit de la Charente sur la capacité biotique du bassin ostréicole de Marennes-Oléron. In: Rap. Convention EPR PoitouCharentes IFREMER du 07/02/1985 et Aide du Fond de Dév. Rech. Technol. (M.E.R.S. 86-J00J1). IREMER, L'Houmeau, p. 23-63

This article was submitted to the editor
Schnepf, E., Elbrächter, M. (1988). Cryptophycean-like double membrane-bound chloroplast in the dinoflage]late, Dinophysis ehrenb.: evolutionary, phylogenetic and toxicological implications. Botanica Acta 101: 196-203

Séchet, V., Safran, P., Hovgaard, P., Yasumoto, T (1990). Causative species of diarrhetic shellfish poisoning (DSP) in Norway. Mar. Biol. 105: 269-274

Sieburth, J. McN. (1991). The Pettaquamscutt Lakes. A captive estuary for studying global warming. Maritimes 35 (2): $8-9$

Smayda, T J. (1980). Phytoplankton species succession. In: Morris, I. (ed.) The physiological ecology of phytoplankton. Blackwell Scientific Publ., Boston, p. 493-570

Smayda, T J. (1990). Novel and nuisance phytoplankton blooms in the sea: evidence for a global epidemic. In: Granéli, E., Sundström, B., Edler, L., Anderson, D. M (eds.) Toxic marine phytoplankton. Proc. 4th Int. Conf. Toxic Mar. Phytoplank., 26-30 June 1989, Lund, Sweden. Elsevier, New York, p. 29-40

Sommer, U. (1988). Some size relationships in phytoflagellate motility. Hydrobiologia 161: 125-131

Sournia, A. (1982). Form and function in marine phytoplankton. Biol. Rev. 57: 347-394

Stamman, E., Segar, D. A., Davis, P. G. (1987). A preliminary epidemiological assessment of the potential for Diarrhetic Shellfish Poisoning in the Northeast United States. NOAA techn. Memo, U.S. Dep. Commerce, NOS/OMA 34

Strickland, J. D. H., Parsons, T R. (1972). A practical handbook of seawater analysis, 2nd edn. Bull. Fish. Res. Bd Can. 167: 1-310

Thomas, W. H., Gibson, C. H. (1990). Effects of small-scale turbulence on microalgae. J. appl. Phycol. 2: 71-77

Utermöhl, H. (1931). Neue Wege in der quantitativen Erfassung des Planktons. Verh. int. Verein. Limnol. 5: $567 \mathrm{p}$

Yasumoto, T., Oshima, Y., Sugawara, W., Fukuyo, Y., Oguri, H., Igarashi, T., Kujita, N. (1980). Identification of Dinophysis fortii as the causative organism of Diarrhetic Shellfish Poisoning. Bull. Jap. Soc. scient. Fish. 46(11): 1405-1411

Yentsch, C. S., Menzel, D. W. (1963). A method for the determination of phytoplankton and pheophytin by fluorescence. Deep Sea Res. 10: 221-231

Manuscript first received: August 17, 1992

Revised version accepted: October 14, 1992 